\title{
KAJIAN ANALISIS KETIDAKPASTIAN TLD POSTAL IAEA/WHO SEBAGAI STANDAR PROGRAM AUDIT DOSIS
}

\author{
Nazaroh
}

\begin{abstract}
The International Atomic Energy Agency (IAEA) and World Health Organization (WHO) operate the IAEA/WHO TLD postal dose audit programme using thermoluminescence dosimeter (TLDs) for Secondary Standard Dosimetry Laboratory (SSDL) and user every year. As National Reference Laboratory in the field of radiation metrology, PTKMR - BATAN always participates in the postal dose audit programme on therapy level for 60Co beam. On the postal dose audit programme, the uncertainties in the dose determination from TLD measurements have been evaluated by IAEA, which is comprises of uncertainties in the calibration coefficient of the TLD system and uncertainties in factors correcting for dose response non linearity, fading of TL signal, energy response, and influence of TLD holder. The individual uncertainties then have been combined to estimate the total uncertaintiy in the dose evaluated from TLD measurements. The combined relative standard uncertainty in the dose determined from TLD measurements has been estimated to be $1.2 \%$ for irradiation with 60Co gamma rays and $1.6 \%$ for irradiation with high-energy X-rays. Results from irradiations by Bureau Internationale des Poids et Mesures (BIPM), Primary Standard Dosimetry Laboratory (PSDL), and SSDL compare favourably with the estimated uncertainties, whereas TLD results of radiotherapy centres show higher standard deviations than those derived theoretically. This paper presented the result of TLD postal dose audit for 60Co beam owned by PTKMR-BATAN in the year of 2006-2008.
\end{abstract}

Keywords: $T L D$, uncertainty type $A$, uncertainty type $B$, combined uncertainty

\section{PENDAHULUAN}

Dalam setiap pengukuran, sering kita dihadapkan pada istilah kepresisian keakurasian, dan ketidakpastian dari alat yang kita gunakan. Keakurasian adalah kedekatan antara hasil pengukuran dan nilai sebenarnya dari besaran ukur tersebut. Keakurasian menunjukkan deviasi bacaan dari input yang diketahui. Sedangkan Kepresisian adalah kemampuan alat untuk mengulang kembali bacaan tertentu.

Menurut Jimmy Pusaka, (2001): Pengertian dan Pemahaman Ketidakpastian Pengukuran [1], ketidakpastian pengukuran adalah parameter hasil pengukuran yang mengkarakterisasi dispersi nilai yang dapat dikenakan pada besaran ukur. Hal ini seperti yang diungkapkan dalam ISO/IEC/OIML/BIPM, 1995[2]: Guide to The Expression of Uncertainty in Measurement. Uncertainty of measurement is a parameter, associated with the result of a measurement, that characterizes the dispersion of the values that could reasonably be attributed to the measurand. Ketidakpastian pengukuran merupakan nilai mungkin (possible value) dari kesalahan pengukuran [3] dan nilainya bervariasi bergantung pada lingkungan percobaan.

Untuk mempertahankan kompetensi suatu laboratorium dan untuk memenuhi kebutuhan ketertelusuran internasional dalam pengukuran dosis radiasi, setiap tahun Pusat Teknologi Keselamatan dan Metrologi Radiasi - Badan
Tenaga Nuklir Nasional (PTKMR-BATAN) selaku Laboratorium Acuan Nasional di bidang metrologi radiasi selalu mengikuti interkomparasi audit dosis tingkat terapi menggunakan Thermoluminescence Dosimeter (TLD) postal yang diselenggarakan oleh IAEA/WHO (International Atomic Energy Agency/World Health Organization). Kebutuhan akan ketertelusuran internasional untuk pengukuran dosis radiasi ini telah dirintis dunia metrologi radiasi sejak awal tahun 1960-an yaitu ketika diperkenalkan untuk pertama kalinya tentang ketepatan dosimetri tingkat industri (khususnya pada proses sterilisasi), terapi radiasi berkas eksternal, brakhiterapi, dan pada terapi sumber terbuka (kedokteran nuklir), di mana hasil terapi bergantung pada ketepatan dosis radiasi yang diberikan ke pasien.

Secara umum, kegiatan interkomparasi ini sangat penting karena dapat mendukung implementasi program audit mutu pada setiap level rantai pengukuran, dan dapat memberikan kepercayaan yang lebih kepada laboratorium tersebut. Jejaring kegiatan interkomparasi ini tidak hanya membantu anggota SSDL (Secondary Standard Dosimetry Laboratory) mencapai kepercayaan dalam kemampuan pengukuran tetapi juga memfasilitasi kerjasama internasional dan melengkapi ketahanan untuk sistem pengukuran keseluruhan.

Tujuan khusus keikutsertaan dalam interkomparasi TLD postal adalah untuk memverifikasi dosis pesawat terapi milik SSDL 
atau user. Verifikasi dosis adalah cara yang paling tepat untuk memeriksa ketepatan pengukuran dosis. Apabila dosis yang dinyatakan oleh user atau SSDL dibandingkan dengan dosis yang diukur IAEA masih dalam rentang $\pm 3,5 \%$ maka dianggap memuaskan.

TLD postal telah digunakan oleh IAEA/WHO sebagai basis/dasar program audit dosis radioterapi sejak tahun 1969 (Izewska dan Andreo, 2000) [4]. Pada pelaksanaan program tersebut, sekitar 1500 pusat radioterapi (sebagian besar dari negara berkembang), ikut berpartisipasi. Secara tidak langsung, hasil kegiatan interkomparasi ini dapat memverifikasi audit dosis berkas $60 \mathrm{Co}$ dan sinar-X energi tinggi dari akselerator medik milik partisipan. Dengan cara yang sama pula, IAEA/WHO memeriksa konsistensi dosimetri diantara anggota-anggota jejaring SSDL-IAEA/WHO.

Setiap tahun, ada 50-60 laboratorium (termasuk PTKMR BATAN), ikut berpartisipasi pada program audit dosis ini. IAEA mengirimkan 3 buah TLD yang harus disinari oleh partisipan satu demi satu, dengan dosis 2 Gy pada rentang waktu yang telah ditentukan. Partisipan harus mengirimkan kembali TLD tersebut ke IAEA pada waktu yang telah dijadwalkan. Oleh IAEA, TLD partisipan dibaca, dianalisa dan ditentukan dosis serapnya. Paralel dengan waktu iradiasi/penyinaran oleh partisipan, IAEA menyinari TLD acuan yang digunakan untuk proses evaluasi dosis tersebut. Dosis yang diterima TLD dibandingkan dengan dosis yang dinyatakan oleh pusat radioterapi atau SSDL.

Untuk membaca/mengevaluasi dosis TLD, IAEA menggunakan TLD-reader dan untuk menghitung ketidakpastiannya digunakan ISO/IEC/ OIML/BIPM/1995: Guide to the Expression of Uncertainty in Measurement. Untuk menghitung ketidakpastian TLD, laboratorium Dosimetri IAEA menggunakan data percobaan dari tahun 2001-2005.

Pada makalah ini disajikan Analisis Ketidakpastian TLD postal IAEA/WHO dan keikutsertaan PTKMR - BATAN pada Program Audit Dosis yang diselenggarakan oleh IAEA/WHO.

\subsection{Keikutsertaan PTKMR-BATAN pada Program Audit Dosis IAEA/WHO}

Pada program audit dosis tahun 2006, TLD batch yang dikirimkan ke PTKMR adalah DL0626, sebanyak 3 buah. Demikian pula untuk tahun 2007 dikirim 3 buah TLD dalam kapsul dengan nomor batch DL 0725 dan tahun 2008 dengan nomor batch DL 0826. TLD tersebut harus disinari oleh partisipan sesuai dengan ketetapan IAEA yaitu antara 15-30 Mei.

Tahapan yang harus dilakukan oleh partisipan pada setiap interkomparasi adalah:

a. Mengukur berkas luaran pesawat 60Co atau sinar-X Megavoltage

b. Menghitung waktu penyinaran agar dosis yang diberikan pada TLD tepat 2 Gy

c. Mengirradiasi TLD sesuai instruksi teknis

d. Mengisi lembar data yang telah diberikan oleh IAEA

e. Mengembalikan TLD dan lembar data dalam waktu seminggu setelah iradiasi

f. Menghindarkan TLD dari cahaya matahari dan kelembaban yang tinggi.

\subsection{Tujuan Audit TLD}

Tujuan audit TLD adalah untuk memeriksa dosis yang diberikan berkas pesawat 60Co atau sinar$X$ Megavoltage milik laboratorium peserta interkomparasi atau user. Audit dilaksanakan pada kondisi nominal Source to Surface Distance (SSD) dan ukuran lapangan $10 \mathrm{~cm} \mathrm{x}$ $10 \mathrm{~cm}$, pada kedalaman $5 \mathrm{~cm}$ di air (untuk 60Co) dan sinar-X megavoltage pada 10 TPR20 $\leq 0,7$. TPR:Tissue Phantom Ratio.

\section{TEORI}

\subsection{Pengukuran Laju Dosis Serap Air dengan Kamar Pengion}

Sebelum digunakan untuk pengukuran dosis serap, sistem dosimeter milik PTKMR - BATAN (detektor kamar pengion 0,6 cc, NE2571/3154 dan dosimeter Farmer 2570/1B\#1319) dicek terlebih dahulu kestabilannya dengan menggunakan sumber pengecek $90 \mathrm{Sr} \mathrm{S} / \mathrm{N}: 6427$ BA, Aktivitas:10 mCi (1985), dengan waktu paro $(\mathrm{T} 1 / 2)=28,7$ tahun.

Pengecekan awal sistem dosimeter tersebut dilakukan pada tanggal 25 Agustus 2001, dengan bacaan awal $=8,023 \mathrm{nC}$. Pengecekan kestabilan sistem dosimeter pada tanggal 22 Mei 2006 mempunyai bacaan ratarata $=7,105 \mathrm{nC}$. Perbedaan pengecekan tersebut (Bc) dengan pengecekan awal (Ba), setelah dikoreksi dengan faktor peluruhan, sebesar 0,63\%. Menurut Panduan Mutu Laboratorium Metrologi Radiasi PTKMR-BATAN, apabila perbedaan tidak melebihi $1 \%$, sistem tersebut dikatakan stabil dan dapat digunakan untuk pengukuran [5].

Selanjutnya pengukuran laju dosis serap air dari pesawat 60Co dilakukan dengan detektor 
kamar pengion volume 0,6cc (NE 3154) yang dirangkai dengan dosimeter Farmer 2570/1B $\mathrm{S} / \mathrm{N}: 1319$, sesuai protokol dosimetri yang biasa digunakan pada laboratorium peserta interkomparasi, yaitu pada jarak $80 \mathrm{~cm}$, dan ukuran lapangan $10 \mathrm{~cm} \times 10 \mathrm{~cm}$ dan pada kedalaman $5 \mathrm{~cm}$ di air. Pada pengukuran dosis serap ini digunakan protokol IAEA/TRS 374 dan 398 [6.8]. Faktor kalibrasi ND,W dari sistem dosimeter yang digunakan adalah 45,4mGy/nC, $\mathrm{kpol}=1,0042$ dan $\mathrm{ks}=1,006$ dan muatan yang terkumpul pada pengukuran tersebut, $\mathrm{Mu}=$ $0,602 \mathrm{nC} /$ menit sehingga laju dosis serap air pada kondisi tersebut adalah 27,61mGy/menit, dapat dihitung dengan persamaan:

${ }_{5} \mathrm{Dw}=\mathrm{M}_{\mathrm{u}} \cdot \mathrm{N}_{\mathrm{D}, \mathrm{W}} \cdot \mathrm{k}_{\mathrm{pol}} \cdot \mathrm{k}_{\mathrm{s}}[\mathrm{mGy} / \mathrm{menit}]$

Untuk memberikan dosis yang ditentukan dari IAEA (2000 mGy), Di, lama irradiasi, t yang diperoleh adalah 72,44 menit, dapat dihitung dari persamaan berikut:

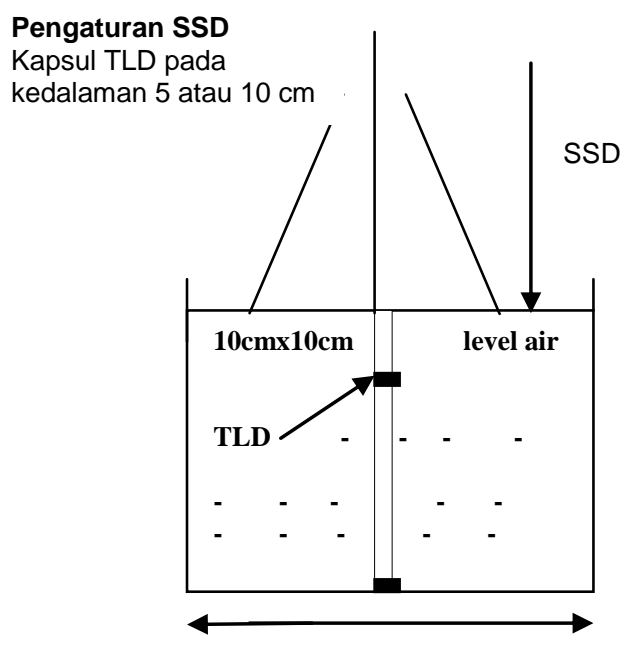

$t=\frac{D_{i}}{D_{w}}$

$\mathrm{D}_{\mathrm{i}} \quad=$ Dosis yang ditentukan IAEA [mGy]

${ }_{5} \mathrm{D}_{\mathrm{w}}=$ laju dosis pesawat, pada jarak $80 \mathrm{~cm}$ [mGy/menit]

$\mathrm{T}=$ waktu yang diperlukan untuk irradiasi [menit]

\subsection{Irradiasi Kapsul TLD oleh Partisipan}

a. Sebelum dilakukan iradiasi/penyinaran, pelurusan, ukuran lapangan, level air dan jarak diperiksa kembali, apakah sudah benar/belum (Gambar 2)

b. Kapsul TLD diselipkan ke dalam holder.

c. Kapsul TLD di-iradiasi/disinari dengan dosis yang telah ditentukan

d. Kapsul diambil dari holder dan dikeringkan

e. Prosedur untuk langkah 2 sampai 4 diulangi untuk kapsul yang lain

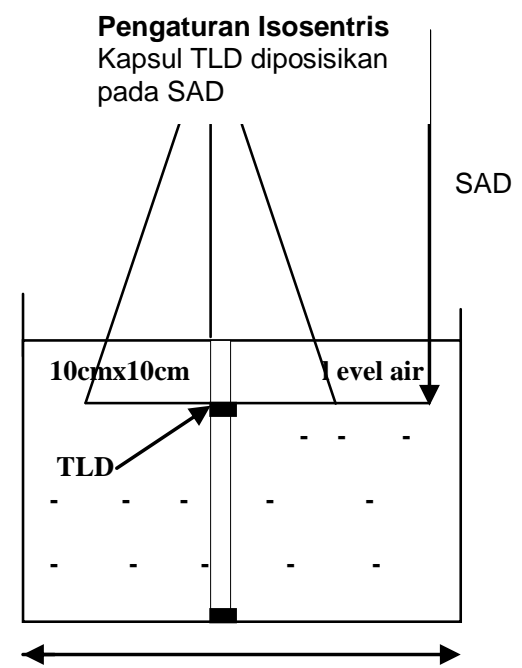

Gambar 1 Pengaturan Geometri untuk Irradiasi TLD dengan Berkas Vertikal

\subsection{Evaluasi Dosis oleh IAEA [7, 12]}

Dosis serap dari pengukuran TLD ditentukan dengan persamaan berikut:

$D_{T L D}=M \cdot N \cdot f_{\text {lin }} \cdot f_{E} \cdot f_{\text {fad }} \cdot f_{\text {hol }}$

M: bacaan TLD (counts)

$\mathrm{N}$ : koefisien kalibrasi sistem TLD (Gy/counts)

$f_{\text {lin: }}$ faktor koreksi ketidaklinieran respon dosis

$\mathrm{f}_{\mathrm{E}}$ : faktor koreksi energi

$\mathrm{f}_{\text {fad }}$ : faktor koreksi fading

75 $\mathrm{f}_{\text {hol }}$ : faktor koreksi holder TLD

Diasumsikan bahwa faktor-faktor pada persamaan tersebut tidak berkorelasi satu sama lain. Jadi, ketidakpastian standar relatif gabungan, $u_{c}\left(D_{T L D}\right)$ pada dosis yang ditentukan dari pengukuran TLD adalah akar dari jumlah ketidakpastian relatif individu:

$u_{c}\left(D_{\text {TDD }}\right)=\sqrt{u(M)^{2}+u(N)^{2}+u\left(f_{\text {fad }}\right)^{2}+u\left(f_{\text {hol }}\right)^{2}+u\left(f_{E}\right)^{2}+u\left(f_{\text {lin }}\right)^{2}}$

$\mathrm{U}_{\mathrm{c}}\left(\mathrm{D}_{\text {stat }}\right)$ adalah ketidakpastian gabungan yang dinyatakan oleh user.

Ketidakpastian gabungan uc(DTLD/Dstat) yaitu: 


$$
u_{c}\left(\frac{D_{T L D}}{D_{\text {stat }}}\right)=\sqrt{\frac{\left[u_{c}\left(D_{T L D}\right)^{2}+u_{c}\left(D_{\text {stat }}\right)^{2}\right]}{L}}
$$

$\mathrm{L}$ : jumlah dosimeter $\mathrm{TL}$

Ketidakpastian gabungan $\mathrm{u}_{\mathrm{C}}\left(\mathrm{D}_{\mathrm{TLD}} / \mathrm{D}_{\text {stat }}\right)$ adalah deviasi standar dari distribusi statistik untuk sejumlah besar TLD yang dimiliki IAEA/WHO. Ketidakpastian gabungan $\mathrm{u}_{\mathrm{C}}\left(\mathrm{D}_{\mathrm{TLD}} / \mathrm{D}_{\text {stat }}\right)$ diperoleh dari data percobaan tahun 2001-2005 yang dilakukan oleh SSDL/IAEA dibandingkan dengan estimasi dari persamaan (5).

\section{TATA KERJA}

Sistem TLD-IAEA untuk dosimetri radioterapi telah diuraikan oleh Izewska et al., $2000^{[5] .}$ Bahan TLD yang digunakan pada program interkomparasi ini adalah bubuk lithium fluorida yang dikotori dengan Mg:Ti $\rightarrow \mathrm{LiF}$ (Mg:Ti), dengan tipe TLD-100 (Harshaw). Sebanyak 165 mg bubuk LiF (Mg:Ti) dimasukkan ke dalam kapsul polyethilen kedap air yang berdimensi panjang bagian dalam $20 \mathrm{~mm}$, dan diameter dalam $3 \mathrm{~mm}$. Setelah disinari, oleh IAEA TLD tersebut dibaca dengan reader PCL-3 otomatis (Fimel) dengan dua langkah putaran pemanasan yaitu pemanasan awal $130^{\circ} \mathrm{C}$ dan pemanasan utama $300^{\circ} \mathrm{C}$. Waktu integrasi selama 25 detik. Selama pembacaan TL, digunakan gas nitrogen kering.

Untuk setiap kapsul, dilakukan $4 \mathrm{x}$ pembacaan. Untuk itu, powder dibagi dalam empat bagian menggunakan dispenser TLD (Teledyne), yaitu masing-masing sekitar 41-42 mg. Kedapat ulangan masa bubuk diverifikasi secara periodik dan untuk setiap lot powder baru, kepresisian dalam penentuan dosis diverifikasi dengan sistem TLD, yang dilaksanakan dengan self-test di laboratorium Dosimetri IAEA.

Untuk kontrol mutu eksternal, IAEA/WHO mengajak BIPM dan 6 PSDL serta pusat-pusat radioterapi, SSDL/universitas acuan (yang berpengalaman luas di dalam radioterapi) untuk berpartisipasi dalam menyinari TLD. Institusi tersebut menyinari TLD dengan dosis serap yang terdefinisi dengan baik dari berkas ${ }^{60} \mathrm{Co}$ dan sinar-X energi tinggi. Selanjutnya dosimeter tersebut dianalisa IAEA bersamaan dengan TLD yang dikembalikan oleh partisipan (pusat radioterapi atau SSDL). Hasil iradiasi acuan tersebut digunakan untuk memverifikasi konsistensi kalibrasi sistem TLD IAEA dan juga untuk studi ketidakpastian sistem audit dosis TLD postal IAEA/WHO.

\section{HASIL DAN DISKUSI}

Ketidakpastian standar gabungan (combined standard uncertainty) untuk pengukuran dosis TLD digabungkan dengan ketidakpastian penentuan dosis serap air pada berkas ${ }^{60} \mathrm{Co}$, dimana TLD-IAEA telah diiradisi dan ketidakpastiannya digabungkan dengan sistem TLD. Jadi ketidakpastian pada koefisien kalibrasi TLD berasal dari penentuan dosis ${ }^{60} \mathrm{Co}$, iradiasi tersebut dan bacaan kapsul TLD. Penentuan dosis ${ }^{60} \mathrm{Co}$ dilakukan dengan pengukuran kamar ionisasi di air menggunakan protokol IAEA/TRS398 (IAEA, 2000) $^{[6,8]}$. Ketidakpastian gabungan pengukuran kamar ionisasi di dalam air, utamanya berasal dari kalibrasi kamar ionisasi, ketidakpastian posisi kamar ionisasi dan ketidakpastian yang terkait dengan besaran yang mempengaruhinya, seperti temperatur dan tekanan.

Komponen-komponen yang mengontribusi ketidakpastian laju dosis ${ }^{60} \mathrm{Co}$ adalah tipe $\mathrm{A}$ dan tipe B. Ketidakpastian pada waktu iradiasi TLD diasumsikan berasal dari resolusi timer, sedangkan evaluasi ketidakpastian posisi TLD pada fantom diperkirakan dari distribusi rectangular. Ketidakpastian pada bacaan ratarata kapsul TLD IAEA dihitung dengan rata-rata aritmatika dengan distribusi kesalahan standar dari 10.000 TLD yang telah diirradiasi dengan dosis yang sama oleh BIPM, PSDL, SSDL dan pusat radioterapi.

Komponen Ketidakpastian tipe A lainnya adalah koreksi fading, koreksi peluruhan dan koreksi holder. Koreksi fading dihitung dari distribusi rata-rata ketidakpastian koreksi fading untuk sejumlah TLD, dan koreksi peluruhan dilakukan terhadap perbedaan waktu iradiasi dan bacaan acuan IAEA dan kapsul partisipan. Ketidakpastian pada faktor koreksi holder telah dilakukan oleh Izewska, $1996^{[9]}$.

Ketidakpastian tipe A terhadap respon energi telah dilakukan oleh pusat radioterapi universitas acuan. Ketidakpastian koreksi energi ini ditentukan dari distribusi sekitar 200 dosimeter IAEA yang diiradiasi dengan sumber radiasi yang berbeda ${ }^{[13]}$.

Ketidakpastian faktor koreksi ketidaklinieran respon dosis ditentukan oleh IAEA dengan cara mengiradiasi 300 kapsul TLD dengan variasi dosis dalam beberapa sesi selama tahun 2001-2005 .

Sertifikat hasil TLD IAEA/WHO tidak hanya memberikan nilai dosis dari pengukuran TLD tetapi juga yang dinyatakan partisipan, rasio dosis $D_{\text {TLD }} / D_{\text {stat. }} D_{\text {TLD }}$ adalah dosis TLD yang dibaca/dievaluasi oleh IAEA sedangkan $D_{\text {stat }}$ 
adalah dosis TLD yang dinyatakan peserta. Ketidakpastian $u_{\mathrm{c}}\left(\mathrm{D}_{\mathrm{TLD}}\right)$, diperoleh dari persamaan (4) dan $u_{c}\left(D_{\text {stat }}\right)$ ketidakpastian yang dinyatakan oleh peserta interkomparasi.

Tabel 1 menyajikan ketidakpastian standar relatif (satu deviasi standar, dalam \%) dan ketidakpastian gabungan pada dosis yang ditentukan. Komponen utama pada ketidakpastian TLD adalah ketidakpastian pada bacaan TLD per kapsul 0,48\% (Tabel 1). Ketidakpastian pada koefisien kalibrasi TLD, $\mathrm{N}=$ $0,46 \%$ berasal dari tipe $A(0,39 \%)$ dan tipe $B$ $(0,24 \%)$.

Tabel 1 Ketidakpastian Standar Relatif (dalam \%), dan Ketidakpastian Gabungan pada Dosis, dievaluasi oleh IAEA $[7,12]$

\begin{tabular}{|c|c|c|c|}
\hline Faktor & Tipe A (\%) & Tipe B (\%) & Gabungan A, B (\%) \\
\hline $\mathrm{M}$ & 0,48 & & 0,48 \\
\hline $\mathrm{N}$ & 0,39 & 0,24 & 0,46 \\
\hline $\mathrm{f}_{\text {lin }}$ & 0,90 & & 0,90 \\
\hline $\mathrm{F}_{\mathrm{E}}$ & 1,10 & & 1,10 \\
\hline $\mathrm{f}_{\mathrm{fad}}$ & 0,02 & & 0,02 \\
\hline $\mathrm{f}_{\text {hol }}$ & 0,30 & & 0,30 \\
\hline Berkas Co-60 & 1,14 & 0,24 & 1,16 \\
\hline Sinar-X energi tinggi & 1,58 & 0,24 & 1,60 \\
\hline
\end{tabular}

Penyumbang terbesar ketidakpastian standar relatif gabungan diperoleh untuk faktor koreksi energi, $\mathrm{f}_{\mathrm{E}}$ untuk sinar- $\mathrm{X}$ energi tinggi, dan faktor koreksi ketidaklinieran respon dosis, $f_{\text {lin }}$ dengan ketidakpastian masing-masing 1,10\% dan $0,90 \%$. Sedangkan ketidakpastian faktor koreksi fading sangat kecil. Hal ini dapat diminimasi dengan waktu irradiasi acuan IAEA dan TLD partisipan sedekat mungkin .

Deviasi standar relatif dari 10.751 TLD yang diamati oleh IAEA adalah $0,48 \%$ dan distribusi ketidakpastian koreksi fading sebagai fungsi perbedaan waktu antara irradiasi acuan IAEA dan TLD partisipan berdasarkan pada 2728 set TLD yang dievaluasi pada tahun 20012005. Perbedaan waktu rata-rata adalah 10 hari dan ketidakpastiannya $0,002 \%$.

Ketidakpastian standar relatif gabungan TLD untuk berkas ${ }^{60} \mathrm{Co}$ adalah $1,16 \%$ (Tabel 1) dapat dibandingkan terhadap ketidakpastian RPC (Radiological Physics Center) di USA (Kirby et al, 1992) [10], yaitu $2,3 \%$ dan $1,6 \%$ untuk sistem TLD EQUAL (Ferreira et al, 2000) ) $^{[11]}$ Kontributor terbesar ketidakpastian pada sistem TLD RPC adalah ketidakpastian bacaan TLD individu, yaitu $1,5 \%$. Ketidakpastian untuk faktor koreksi energi sinar-X pada sistem TLD RPC adalah $1,1 \%$, hampir sama dengan ketidakpastian faktor koreksi energi sinar-X .

\subsection{Ketidakpastian TLD}

Ketidakpastian $D_{T L D} / D_{\text {stat }}$ yang diperoleh IAEA/WHO diturunkan dari distribusi statistik hasil percobaan TLD pada tahun 2001-2005, yang disajikan pada Tabel $2^{[7]}$. Hasil iradiasi acuan $\left(D_{T L D} / D_{\text {stat }}\right)$ yang disajikan oleh BIPM dan 6 PSDL untuk 95 set TLD (tiap set 3 TLD), meliputi $77{ }^{60} \mathrm{Co}$ dan 18 berkas sinar-X energi tinggi. Untuk ${ }^{60}$ Co rata-rata $\left(D_{T L D} / D_{\text {stat }}\right)=1,002 \pm$ $0,7 \%$ dan untuk berkas sinar- $\mathrm{X}$ energi tinggi ratarata $\left(D_{T L D} / D_{\text {stat }}\right)=1,003 \pm 1,0 \%$. Ketidakpastian dosis serap air $u_{c}\left(D_{\text {stat }}\right)$ pada posisi berkas ${ }^{60} \mathrm{Co}$ dari radiasi BIPM dan beberapa PSDL adalah $0,5 \%$ seperti yang dinyatakan oleh laboratorium tersebut. Diasumsikan bahwa PSDL lain memiliki ketidakpastian yang sama. Dengan menggunakan $u_{c}\left(D_{\text {stat }}\right) \quad 0,5 \%$ dan $u_{c}\left(D_{T L D}\right)$ dari Tabel 1, ketidakpastian $\quad u_{c}\left(D_{T L D} / D_{\text {stat }}\right)$ memberikan nilai $0,7 \%$ untuk berkas ${ }^{60} \mathrm{Co}$ dan $1 \%$ untuk sinar- $X$ energi tinggi. Nilai tersebut bersesuaian dengan data percobaan (Tabel 2).

Hasil dari 328 pengecekan berkas SSDL (240 berkas Co-60 dan 88 berkas sinar-X energi tinggi), dianalisa menggunakan protokol IAEATRS - $398 \quad\left(\right.$ IAEA-2000) ${ }^{[6,8]}$. Estimasi Ketidakpastian $\quad \mathrm{u}_{\mathrm{c}}\left(\mathrm{D}_{\mathrm{TLD}} / \mathrm{D}_{\text {stat }}\right)$ dibandingkan dengan distribusi hasil SSDL cukup baik (Tabel 2).

Hasil dari pengecekan 537 berkas pusat radioterapi (184 berkas Co-60 dan 353 berkas sinar-X energi tinggi) selama periode 2001-2005 menggunakan protokol IAEA-TRS-398 (IAEA- 
2000) dan dianalisa dengan cara yang sama, memberikan ketidakpastian seperti yang tersaji pada Tabel 2. Seperti yang terlihat pada Tabel 2, ketidakpastian standar relatif $\left(D_{T L D} / D_{\text {stat }}\right)$ yang diturunkan dari hasil TLD lebih tinggi dari estimasi menggunakan persamaan (5) untuk pusat radioterapi baik untuk ${ }^{60} \mathrm{Co}$ dan sinar-X energi tinggi. Hal ini mungkin disebabkan oleh ketidakpastian kalibrasi yang dilakukan SSDL lebih tinggi, sistem dosimetri yang digunakan oleh pusat radioterapi, ketidakpastian pada setup geometri untuk irradiasi TLD, dan kinerja peralatan radioterapi di pusat radioterapi tersebut.

Pada Tabel 3 disajikan hasil interkomparasi IAEA/WHO TLD Postal Dose Quality Audit yang diikuti oleh PTKMR pada tahun 2006, 2007 dan 2008.

Tabel 2 Ketidakpastian Standar Relatif $u_{c}\left(D_{T L D} / D_{\text {stat }}\right)$, Dihitung dengan Persamaan (5) ${ }^{[7]}$

\begin{tabular}{|c|c|c|c|c|}
\hline Institusi & \multicolumn{2}{|c|}{ Co-60 } & \multicolumn{2}{c|}{ Sinar-X energi tinggi } \\
\hline & estimasi & percobaan & estimasi & percobaan \\
\hline BIPM dan 6 PSDL & 0,7 & 0,7 & 1,0 & 1,0 \\
\hline 328 SSDL & 0,8 & 1,1 & 1,2 & 1,1 \\
\hline 537 Rumahsakit & 1,1 & 2,6 & 1,6 & 2,1 \\
\hline
\end{tabular}

Tabel 3 Hasil Interkomparasi IAEA/WHO TLD Postal Dose Quality Audit yang diikuti PTKMR Tahun 2006-2008

\begin{tabular}{|c|c|c|c|c|c|c|c|c|}
\hline Year & Beam & $\begin{array}{c}\text { Radiation } \\
\text { Unit }\end{array}$ & $\begin{array}{l}\text { TLD } \\
\text { Set }\end{array}$ & $\begin{array}{l}\text { User } \\
\text { Stated } \\
\text { Dose } \\
\text { (Gy) }\end{array}$ & $\begin{array}{c}\text { IAEA } \\
\text { (measured } \\
\text { Dose) } \\
\text { (Gy) }\end{array}$ & $\begin{array}{l}\text { IAEA } \\
\text { mean } \\
\text { dose } \\
(G y)\end{array}$ & $\begin{array}{l}\% \text { dev. } \\
\text { Rel. To } \\
\text { IAEA } \\
\text { mean } \\
\text { dose }\end{array}$ & $\begin{array}{c}\text { IAEA } \\
\text { mean } \\
\text { dose/user } \\
\text { stated } \\
\text { dose }\end{array}$ \\
\hline \multirow[t]{3}{*}{2006} & Co-60 & $\mathrm{V} 4 \mathrm{M} / 60$ & $\begin{array}{c}\mathrm{DL} \\
0626\end{array}$ & 2.00 & 2.01 & & & \\
\hline & & & & 2.00 & 1.98 & 1.98 & 0.90 & 0.99 \\
\hline & & & & 2.00 & 1.95 & & & \\
\hline \multirow[t]{3}{*}{2007} & Co-60 & Cirrus & $\begin{array}{c}\mathrm{DL} \\
0725\end{array}$ & 2.01 & 2.03 & & & \\
\hline & & & & 2.01 & 2.06 & 2.04 & -1.7 & 1.02 \\
\hline & & & & 2.01 & 2.04 & & & \\
\hline \multirow[t]{3}{*}{2008} & Co-60 & Cirrus & $\begin{array}{c}D L \\
0826\end{array}$ & 2.00 & 2.00 & & & \\
\hline & & & & 2.00 & 1.99 & 2.00 & -0.1 & 1.00 \\
\hline & & & & 2.00 & 2.01 & & & \\
\hline
\end{tabular}

Pada tahun 2006, berkas ${ }^{60} \mathrm{Co}$ yang digunakan adalah V4M/60, dengan \% deviasi relatif terhadap IAEA sebesar 0,9\%. Pada tahun 2007 berkas ${ }^{60} \mathrm{Co}$ yang digunakan adalah Cirrus, berkas tersebut belum diletakkan pada posisi yang sebenarnya (masih berkedudukan sementara di ruang netron, Pasar Jum'at). Ruangan belum memadai, meja kalibrasi dan pengaturan jarak tidak ada, sehingga \% deviasi relatif TLD yang dinyatakan PTKMR dan IAEA cukup besar, yaitu $-1,7 \%$ sedangkan pada tahun 2008 berkas ${ }^{60} \mathrm{Co}$ telah diletakkan pada posisi yang sebenarnya di kantor BATAN pusat. dan $\%$ deviasi relatif TLD yang dinyatakan PTKMR dan IAEA adalah $-0,1 \%$. Bila perbedaan dengan IAEA masih di bawah 3,5\% berarti pengukuran dosis yang dilakukan PTKMR cukup baik. 


\section{KESIMPULAN}

Studi ketidakpastian evaluasi dosis TLD pada program audit dosis postal terdiri atas ketidakpastian koefisien kalibrasi sistem TLD, ketidakpastian faktor koreksi fading, pengaruh holder, ketergantungan energi dan ketidaklinieran respon dosis. Estimasi ketidakpastian standar relatif gabungan $\mathrm{u}_{\mathrm{c}}\left(\mathrm{D}_{T L \mathrm{D}} / \mathrm{D}_{\text {stat }}\right)$ pada dosis yang dievaluasi dari pengukuran TLD sebesar $1,2 \%$ untuk ${ }^{60} \mathrm{Co}$ dan $1,6 \%$ untuk sinar- $X$ energi tinggi.

Ketidakpastian rasio dosis yang dievaluasi IAEA dan yang dinyatakan partisipan, $\mathrm{u}_{\mathrm{c}}\left(\mathrm{D}_{\mathrm{TLD}} / \mathrm{D}_{\text {stat }}\right)$ juga dievaluasi. Hal ini bergantung pada prosedur TLD dan prosedur dosimetri lokal, yang meliputi kode praktek dosimetri yang digunakan. Pendekatan teoritis menggunakan persamaan (5) untuk estimasi $u_{c}\left(D_{T L D} / D_{\text {stat }}\right)$ dengan menggabungkan ketidakpastian $\mathrm{u}_{\mathrm{c}}\left(\mathrm{D}_{\mathrm{TLD}}\right)$ pada dosis TLD dan $\mathrm{u}_{\mathrm{c}}\left(\mathrm{D}_{\text {stat }}\right)$, dosis yang dinyatakan partisipan. Hasil ini divalidasi terhadap data percobaan BIPM, PSDL, dan SSDL. Hasil iradiasi TLD yang dilaksanakan BIPM, PSDL dan SSDL dibandingkan juga dengan ketidakpastian yang diestimasi oleh IAEA.

TLD dari pusat radioterapi menunjukkan deviasi standar lebih tinggi, dibandingkan dengan estimasi IAEA. Hal ini disebabkan oleh adanya tambahan ketidakpastian pada praktek dosimetri di pusat radioterapi, yang diuraikan pada protokol IAEA-TRS-398 (IAEA-2000), ketidakpastian standar dosimetri lokal oleh SSDL. Faktor kontributor lainnya adalah ketidakpastian pada set-up geometri untuk iradiasi TLD, dan kinerja peralatan radioterapi di pusat radioterapi tersebut, khususnya untuk berkas ${ }^{60} \mathrm{Co}$ akibat ketidakcukupan program pemeliharaan alat. Faktor ketidakcukupan tersebut harus dipenuhi untuk mencapai level dosimetri yang dikehendaki dalam radioterapi.

\section{DAFTAR PUSTAKA}

1. Ferreira, I. H., Dutreix, A. Chavaudra, J., and Svenson, H. 2000. The Estro Quality Assurance Network (EQUAL), Rad.Onc. 55, 273-284

2. IAEA/WHO TLD POSTAL DOSE QUALITY AUDIT for Co-60 and Megavoltage X-ray Beams, instruction Sheet for SSDL
3. IAEA/WHO TLD POSTAL DOSE QUALITY AUDIT. 2006. Result of TLD Measurements for Co-60 and High Energy Photon

4. Instruksi Kerja -LMR-KAL-14, tentang Pengoperasian detektor NE 2571/3154 dan Elektrometer NE 2570/1319, 2003

5. ISO/IEC/OIML/BIPM. 1995. Guide to the Expression of Uncertainty in Meas

6. Izewska, J., Andreo, P. 2000. The IAEA/WHO TLD Postal Programme for Radiotherapy hospitals, Rad.Onc., 54, 65-67

7. Izewska, J., Bera P., and Vatnitsky, S. 2002. IAEA/WHO TLD Postal Dose Audit Service and High Precision Measurements for Radiotherapy Level Dosimetry, Rad. Prot. Dosim. 101, 387-92

8. Izewska J., Hultqvist, M., Bera P., Analysis of Uncertainties in the IAEA/WHO TLD postal dose audit system, www.sciencedirect.com

9. Izewska, J., Novotny, J., et.al. 1996. The Influence of the IAEA Standard Holder on Dose Evaluated from TLD Samples, Phys., Med. Biol, 41, 465-73

10. Kirby, T.H., Hanson, W.F., and JOHNSTON, D.A. 1992. Uncertainty Analysis of Absorbed Dose Calculation From Thermoluminescence Dosimeters, Med.Phys, 19, 1427-1433

11. Pusaka, J. 2001. Pengertian dan Pemahaman Ketidakpastian Pengukuran, pt. Mitra Mutu Mancanegara

12. Sutisna. 1999. Kontrol Statistik dan Penentuan Ketidakpastian, Semiloka Sistem Mutu Laboratorium Pengujian, Jakarta

13. Technical Report Series, TRS No. 398, IAEA. 2000. Absorbed Dose Determination in External Beam Radiotherapy, An International Code of Practice for Dosimetry Based on Standards of Absorbed Dose to Water, TRS-398, (Vienna IAEA)

14. Technical Report Series, TRS No. 374. 1994. Calibration of Dosimeters Used in Radiotherapy, Vienna

\section{BIODATA}

\section{Nazaroh}

Penulis dilahirkan di Pekalongan pada tanggal 10 Oktober 1961. Penulis adalah peneliti madya di Pusat Teknologi Keselamatan dan Metrologi Radiasi BATAN 